\title{
Mónika Mesterbázi:
}

\author{
THE WAY OUT IS THE WAY IN \\ AN ESSAY ON T. S. ELIOT'S FOUR QUARTETS
}

\section{ATTACHMENT}

To understand the poem or to grasp its meaning, one has to have the whole in mind, and while keeping it there, while it is working in and on us, we are hardly able to articulate the experience. It would be like speaking with the mouth full of ineffable material.

Words strain,

Crack and sometimes break, under the burden,

Under tension, slip, slide, perish,

Decay with imprecision, will not stay in place,

Will not stay still.

(V, "Burnt Norton")

(...) and every attempt

Is a wholly new start, and a different kind of failure

Because one has only learnt to get the better words

For the thing one no longer has to say, or the way in

which

One is no longer disposed to say it.

(V, "East Coker")

And if I say I put down the text and look back on it, how far do I get? 
We had the experience but missed the meaning,

And approach to the meaning restores the experience

In a different form (...)

(II, "The Dry Salvages")

There is, it seems to us,

At best, only a limited value

In the knowledge derived from experience.

The knowledge imposes a pattern, and falsifies,

For the pattern is new in every moment

And every moment is a new and shocking

Valuation of all we have been. (...)

(II, "East Coker")

On the other hand, is my experience of the Four Quartets so elementary that I can quote all these without mocking the whole? Although reading is experience, a poem cannot be called "inarticulate" in the least. Still, even if it uses words for its material, it has to keep its "message" as hidden as possible. When I am quoting Eliot about expressing and wording thoughts and feelings, I am holding these texts in front of me as a shield for my attempt to speak about them.

\section{DETACHMENT}

There is (a) time

The experience of time is not the "topic" of Four Quartets, which is not a thesis on time. But it starts with time so I will begin with it as well. To abuse the metaphor, time is the material of the text. Or the gap in the material. It gives cohesion. Or else, it provides digression.

Looking at the Quartets from a distance, they have the linear succession of a lifetime: childhood, "our first world", in "Burnt Norton", "in the middle way", in "East Coker", "as one becomes older", in "The Dry Salvages", and in "Little Gidding", the anticipation of old age and death. This looks like the framework of a narration. What is begun in the first Quartet ends in the last. Life grows to death and the elements of the universe, each represented in one Quartet, die in turn in "Little Gidding".

But this is a bird's eye view. In fact, by the time we get to the last Quartet, we have met all possible ends. Our memories, begun "in our first world", end up in 
the present, the time of looking back. Birth itself contains death: "That which is only living/ Can only die." ("Burnt Norton"); "In my beginning is my end." ("East Coker"). It is only repeated in Little Gidding, "at the end of the journey":

What we call the beginning is often the end And to make an end is to make a beginning. The end is where we start from."

What begins and ends is also subject to gradual change: the body grows old, light fades, "Houses rise and fall", and there is also an Ecclesiastical time for everything. Repetition takes place in rhythmical patterns: "The dance along the artery,/ The circulation of the lymph/ Are figured in the drift of stars". And there is the endless, either in the metaphysical sense (the universe: "Or say that the end precedes the beginning,/ And the end and the beginning were always there/ Before the beginning and after the end"), or in the metaphorical ("humility is endless"), or in the existential: "There is no end of it, the voiceless wailing,/ No end to the withering of withered flowers"): "Time the destroyer is time the preserver".

And there are moments that do not belong to time, although they exist and return. These seem to give the most important aspect of time. Not the empty moments of strangers on the underground, but the conscious, authentic, "unattended moments", which exist when we do not count and count with time. These moments are not in public time, in the psychological awareness of its passing.

If every aspect of time is represented by a pattern or by an element (the circular by the wheel or the slow rotation of the Earth, the linear and the empty by air, the everlasting and the changing by water and fire - although these interlink in other ways), the unattended moment stands for the centre of motion, the centre of time and the universe: it is the still point. "Give me a still point and I shall turn the world out of its corners." 1 (When Eliot speaks of time he obviously evokes every and any author on the phenomenon of time, before and after him.2 But he does not develop a whole argument, does not give his process of thinking, step by step, with sudden realizations, nor does he provide conclusions about time. What he achieves is the most that can be done in art: he creates the same in

1 The Archimedes' point

2 From Herakleitos, St. Augustine, to Bergson, Einstein or Heidegger. 
form (pattern) as he reveals in words. The text functions as time experience itself. If I do not understand it, I can still feel it.

We had the experience but missed the meaning

What is there at the still point of the turning world? There is:

The inner freedom from the practical desire,

The release from action and suffering, release from the inner

And the outer compulsion, yet surrounded

By a grace of sense, a white light still and moving,

Erbebung without motion, concentration

Without elimination (...)

And to arrive here one has to descend into the "internal darkness", "the darkness of God" where the soul is waiting - without hope or love or thought, yet open, getting ready and able to perceive, "So the darkness shall be the light, and the stillness the dancing".

At the still point we equal ourselves. When we start to think or speak about it, we get out of it. If it is like a point, it has no extension. What there is to tell about it is all beside the point, is elimination. Naturally, when Eliot writes the poem, he "eliminates".

Yet (...)

(...) Time past and time future

Allow but a little consciousness.

To be conscious is not to be in time

But only in time can the moment in the rose-garden,

(...)

Be remembered; involved with past and future.

Only through time time is conquered."

There is a longer explanation of the difference in "The Dry Salvages":

But to apprehend

The point of intersection of the timeless

With time, is an occupation for the saint -

No occupation either, but something given

And taken, in a lifetime's death in love,

Ardour and selflessness and self-surrender.

For most of us, there is only the unattended

Moment, the moment in and out of time (...) 
A lifetime burning in every moment

And there are the other moments of life ("East Coker"):

As we grow older

The world becomes stranger, the pattern more complicated

Of dead and living. Not the intense moment

Isolated, with no before and after,

But a lifetime burning in every moment

And not the lifetime of one man only

But of old stones that cannot be deciphered.

A lifetime is the "form of limitation" which includes the conscious moments together with all other moments that make up a personality, an identity, a life. Which one? Life is the vaguest: "what has been". Though the Four Quartets contains personal, autobiographical allusions, it lacks any narration of an autobiographical writing. In fact, personality is to be found rather in the voice that speaks, in the way it speaks - as far as Eliot is concerned he stays in the background (the poet's mind is the medium for art, the poet is not the man), 3 and, though less than in his earlier poetry, the voice is almost impersonal. But again, who is the one that looks up the places (if revisiting them only in his memory) that are important in the history of his family, his country and religion? This personal intention is then the search for identity.

Yet identity is hard to approach directly, and I would rather mention "the personal experiences of a person", the identity of "the speaker" instead of looking for the author, for it is uncertain where he is. In very plain words, by an argument strictly logical he deceives us around a Moebius tape, the dispossession of the self.4

You say I am repeating

Something I have said before. I shall say it again.

Shall I say it again? In order to arrive there,

To arrive where you are, to get from where you are not,

You must go by a way wherein there is no ecstasy.

In order to arrive at what you do not know

3 See Eliot, "Tradition and Individual Talent"

4 Technically speaking, this is unfortunately an "object trouvé from St. John of the Cross, but intensified with the play on repetition with variation (statement 1. - statement 2. - question) in front of it, which is the same pattern as the whole part. 
You must go by a way which is the way of ignorance.

In order to possess what you do not possess

You must go by the way of dispossession.

In order to arrive at what you are not

You must go through the way in which you are not.

And what you do not know is the only thing you know

And what you own is what you do not own

And where you are is where you are not.

So if I maintain that at the still point we equal ourselves, I can just as well say that here we exclude ourselves. Both statements are valid.

I can only say, there we have been:

But sometimes he does say where: there are the other moments. In this indirect search for identity (done directly), past, future and general times are correlated with places, ending in "Little Gidding" with now and in England.

There are other places

Which also are the world's end, some at the sea jaws,

Or over a dark lake, in a desert or a city -

But this is the nearest, in place and time,

Now and in England.

Some of his places become significant motives of the text, the rose-garden, the yew tree, the hedgerow: he has seen them, they are like old photos ("The evening with the photograph album"), they are echoes in his memory. Other places are shown descriptively, the sea, the houses - here real places are in focus. This is the visitor's view of them 5 , only completed with the visitor's state of mind. Real is the underground world of other people, but that is mentioned as counter-example only, the opposite of the identity to be found.

And there is a symbolic level of places where other people are shown and addressed as travellers on board a symbolic ship, on the journey of life. Symbolic are the rustic village and the churchyard - there is no story told us about them in the Quartets but the ghost of a story is strongly felt around them (and can be looked up in biographical notes).6 Both "East Coker" and "Little Gidding" have

5 Like in the five Landscapes, written before the Four Quartets.

6 e. g. Gardner, The Composition of Four Quartets 
such history, they are real places shown enigmatically: what they mean is more important than what they are.

If the poet does not want to place his conscious moments in time, he often only "times" his places. This is the most typical in the visionary meeting with the purgatorial master:

In the uncertain hour before the morning

Near the ending of interminable night

At the recurrent end of the unending

After the dark dove with the flickering tongue

Had passed below the horizon of his homing

While the dead leaves still rattled on like tin

Over the asphalt where no other sound was

Between three districts whence the smoke arose

I met one walking (...)

("Now and in England", in 1942, these lines meant the London air raids; this is an allusion the happier posterity has to learn from notes.)

\section{Both one and many}

This meeting takes place in a significant, unattended moment, "at this intersection time/ Of meeting nowhere, no before and after", because most likely it happens in a dream. The author's self is split: "So I assumed a double part, and cried/ And heard another's voice cry: 'What! are you here?'/ Although we were not. I was still the same,/ Knowing myself yet being someone other - / And he a face still forming". The message this unidentifiable master ${ }^{7}$ conveys is far less vague: it is about old age, in the sharpest, strictest words; beautiful, cruel and true. No complaint, no inaccuracy would be valid here, and no sympathy, because old age speaks for itself. 8 The only escape is the refining fire of Purgatory.

\section{They can tell you, being dead}

7 See Gardner 64, who quotes Eliot's letter to his friend Hayward: "I think you will recognise that it was necessary to get rid of Brunetto for two reasons. The first is that the visionary figure has now become somewhat more definite and will no doubt be identified by some readers with Yeats though I do not mean anything so precise as that. However. I do not wish to take the responsibility of putting Yeats or anybody else into Hell and I do not want to impute to him the particular vice which took Brunetto there. (...)"

$8 \mathrm{cf}$. "Old men ought to be explorers" - recommended by a presumably younger voice. 
These clear words follow the enigmatic communication of the dead, reporting or foretelling the death of the four elements of the universe, and with them all that was once living or connected with life: feelings, the body, homes, actions done or missed. "They can tell you, being dead" what they "had no speech for, when living": which is apparently quite typical of Eliot's approach towards other people in the Four Quartets. The dead, "Keeping time,/ Keeping the rhythm in their dancing", mean harmony, rhythm, order. They know what we do not know, what they "had no speech for, when living". Whereas people in this world are strangers. Strangers on the underground train with "strained, time-ridden faces/ Distracted from distraction by distraction", where the poet sees "behind every face the mental emptiness deepen/ Leaving only the growing terror of nothing to think about". At the same distance there are anxious worried women, forever waiting, fishermen at the mercy of the sea, voyagers, men whose curiosity searches past and future - strangers.

Now, we come to discover that the moments of agony

(...) are likewise permanent.

With such permanence as time has. We appreciate this

better

In the agony of others, nearly experienced,

Involving ourselves, than in our own.

For our own past is covered by the currents of action,

But the torment of others remains an experience

Unqualified, unworn by subsequent attrition.

People change, and smile: but the agony abides.

Is this irony? Scepticism? Admitting that to study the nature of agony, other people come more handy? If irony, then self-irony as well. No, I don't think the poet has to be "nice". I just wonder. "People change and smile": but there are enough of them for experimenting. Or is that so?

In this world, in this pattern people are things, motives, examples: objects for observation. On the other hand, objects behave like bothered, interrupted persons: "The roses/ Had the look of flowers that are looked at". He is more tactful with them than with people, he just lets them be. ("And the unseen eyebeam crossed" - cf. "The eyes that fix you in a formulated phrase"9)

9 "The Lovesong of J. Alfred Prufrock" 
It seems to me that there are four points each at an equal distance from the consciousness of the thinking mind: children who are not yet aware of themselves, not yet conscious as opposed to the dead who have lost their consciousness, and on another axis, similarly opposed to each other, the empty distraction of other people and the desirable "distraction fit" of the mind.

I found only one place in the text when the poet really turns to someone: "My words echo/ Thus, in your mind." Is it someone with him? Someone who shares his experience or can share his thoughts? For some time I had thought it could be the reader ("You! hypocrite lecteur! - mon semblable, - mon frere!"10), then I found the poem addressed to the poet's wife: 11

No peevish winter wind shall chill

No sullen tropic sun shall wither

The roses in the rose-garden which is ours and ours only

But this dedication is for others to read:

These are private words addressed to you in public.

This text explains something and raises doubts. It explains that the author's personal, private feelings are among the experiences that words cannot describe. We cannot speak about the most important feelings or the most important people around us directly12, and when we address them it is not "for others to read". But if the reader is such a stranger, if publication is public in the negative sense, and still, the self is in the centre (i.e. in the Four Quartets), then who is on which side? (Where you are is where you are not.)

But perhaps it is the other way round. The poet observes his own self just as keenly as he observes others:

See, now they vanish,

The faces and places, with the self which, as it could,

loved them,

To become renewed, transfigured, in another pattern.

\section{Another pattern}

10 The Waste Land

11 "A Dedication to My Wife"

12 Much of Buber's book, Ich und Du deals with the question above. 
It is almost impossible to let the inarticulate speak, whether it consists of emotions, experiences or mental struggles. The metaphors come from warfare:

Is a new beginning, a raid on the inarticulate

And so each venture

With shabby equipment always deteriorating

In the general mess of imprecision of feeling,

Undisciplined squads of emotion. And what there is to

conquer

By strength and submission, has already been discovered

Once or twice, or several times (...)

And on the other hand, another pattern is needed to speak about love "beyond desire". One way is to use aphorisms, abstract terms:

There are three conditions which often look alike

Yet differ completely, flourish in the same hedgerow:

Attachment to self and to things and to persons,

detachment

From self and from things and from persons; and, growing

between them, indifference

Which resembles the others as death resembles life,

Being between two lives - unflowering, between

The live and the dead nettle. This is the use of memory:

For liberation - not less of love but expanding

Of love beyond desire, and so liberation

From the future as well as the past.

\section{The cause and end of movement}

And when he turns to love and faith, he chooses enigmas; this is the other way. Love belongs to the still point: it is unmoving and timeless. In the perfect sense, as it seems, it is "Neither flesh nor fleshless". It is the equilibrium of the soul in itself, having only the limitation of the lifetime.

It would be difficult to separate human and divine or other kinds of love in the Quartets. But earthly love involves another person, or a scene, the rose-garden with children, and is found in time only: in the intensive, unattended moment. Further on, however, "the waste sad time" becomes ridiculous, "stretching before and after" - and the metaphor here reveals the mockery of the body. 
And though "Desire itself is movement/ Not in itself desirable", and "Love is most nearly itself/ When here and now cease to matter", in the earthly sense the poet goes on to suggest movement or desire:

Old men ought to be explorers Here and there does not matter We must be still and still moving Into another intensity

For a further union, a deeper communion

Through the dark cold and the empty desolation (...)

This is perhaps the point where earthly and divine love differ, because the soul is told to wait in the darkness of God without love "For love would be love of the wrong thing". Eliot suggests, I think, that there is an easier stage of love and there is another love, beyond human power, the love of the church. The most enigmatic part of the Quartets, the hospital metaphor of the fourth part of "East Coker" enumerates as many as fourteen paradoxes of faith. (As it is not a crossword puzzle which has to be solved and then forgotten, nor is my approach theological, I will not try to decide whether the wounded surgeon, the dying nurse and the ruined millionaire are three persons or one and the same.) But what is told here in the 17th century metaphysical manner can perhaps be compared to an extract from The Rock, written in a direct way, which shall explain it better:

Why should men love the Church? Why should they love her laws?

She tells them of Life and Death, and of all that they would forget.

She is tender where they would be hard, and hard where they like to be soft.

She tells them of Evil and Sin, and other unpleasant facts.

They constantly try to escape

From the darkness outside and within

By dreaming of systems so perfect that no one will need to be good.

But the man that is will shadow

The man that pretends to be."

(The Rock, VI) 


\section{Either fire or fire}

Of all the paradoxes or oximorons, it is "the frigid purgatorial fires" with the flame of roses that is the most organic one in the text. Both the rose and the fire have several connotations throughout and they "are one" in the ultimate line. The roses are almost persons with "the look of flowers that are looked at". The rose is the motive of the intensive moment, the love of life and of living things. The burnt roses are associated with the death of air: with the death of hope and despair. And fire, as in Heracleitos, is the arché of the universe and organizes the Quartets. It is present in all the different kinds of light (especially in "Little Gidding", "When the short day is brightest, with frost and fire,/ The brief sun flames the ice, on pond and ditches"), it appears together with the ashes of dead materials in "East Coker" ("old timber to new fires,/ Old fires to ashes"), is there in the dancing of the dead, is destructive in a catastrophic sense, then refining, purgatorial and Pentecostal: the communication of the dead is tongued with fire; the death of water and fire is perhaps the mockery of all human intentions; then there is a war-time meaning of fire, "The dark dove with the flickering tongue"; and there is fire in desire and love, though less explicitly, or more symbolically, when the fire and the rose become one.

Having seen all these aspects of the element, and of course in a somewhat simplified way we can interpret the absurdity in the fourth part of "Little Gidding", "The choice of pyre or pyre -/ To be redeemed from fire by fire". On the one hand there must be the unredeemable, the negative senses of fire: the destructive, the inhuman: the fire of catastrophes, of bombers, the guilty: the fire of $\sin$ ("The intolerable shirt of flame") the earthly, the wasted, the imperfect: the fire of desire, (c. f. "love of the wrong thing") - and on the other hand there must be redemption: the divine, refining, purgatorial, Pentecostal fire, which ultimately equals the rose, the fire of Love.

\section{Indifference and liberation}

That was a way of putting it

I feel that I had to put down the burden of my reading of the Four Quartets. But perhaps this is where I should begin writing. In my end is my beginning. 
The poem speaks for itself, it is the reader who needs interpretation. The poem even resists it, especially one that keeps repeating the vanity of "elimination". What else does it resist? "If you do not come too close": you may perceive the whole universe of the text. But this is something you must not want to do - only let happen.

It is the problem of the will then, because I may have simplified and made didactic what was hidden in the texture of the poem, but I was similarly irritated by what I felt a message in it, and perhaps now I shall begin with the ending. I do not like allegory as a device. It is saying one thing instead of another, and not "allowing the inarticulate speak for itself". Or, to correct this statement, I think allegory is too direct in such a complex material. It sticks out. And I have doubts about a conclusion of this kind, when a text is otherwise so rich in material and when its roundness and its structure are able to create an endless universe of its own. I would have appreciated it better if this last line had pointed more into the wholeness of the poem and not out of it. This is too loud. This resembles Beethoven's symphonies more than his quartets.

I have gone on trying, and the dispossession of the self is the point how far I like to follow the voice. The question is, who is deceived. I like the familiar Eliotean voice, his hiding personality, his unmistakable self. A poet does not have to be "confessional" to have a personal tone.

There are sentences that I have possessed ever since I read them in the Quartets. And I possess the experience of reading it over and over. But this world is not my world; mine begins with people. Care. Emotions. Then, of course, values, observance, thought and action. I lack discipline and have other words for prayer. There is the place value for faith, and concepts can be substituted.

I have not spoken about Eliot's love of his country, partly because I am sure there are several things I could have mentioned, and partly because I stressed other aspects of identity. In mine, love of a country also begins with people, "the faces and places". But this is not war-time which would make patriotic feelings stronger.

But something must be wrong with the analysis. When I read the text, its words echo in my mind. When I analyze it, I compare and interpret and feel the difference. How could I distill this from the experience? Or is it perfection of this size that I cannot accept?

Although this universe is endless, its still point, the identity is impregnable ("this dedication is for others to read"). It leaves one with the ambiguity of 
attachment, detachment or indifference. But it is liberating as well, makes one identify or differ, or map one's own world.

And there is also the unattended moment of reading: "you are the music while the music lasts. These are only hints and guesses; and the rest" - The rest is different.

\section{REFERENCES}

Eliot, T. S.: The complete Poems and Plays, London: Faber and Faber, 1989.

Eliot, T. S.: "Tradition And the Individual Talent", in Selected Essays London:Faber and Faber, 1932

Gardner, Helen: The Composition of Four Quartets London: Faber and Faber, 1978

Buber, Martin: Ich und Du Munchen - Heidelberg, 1962. 